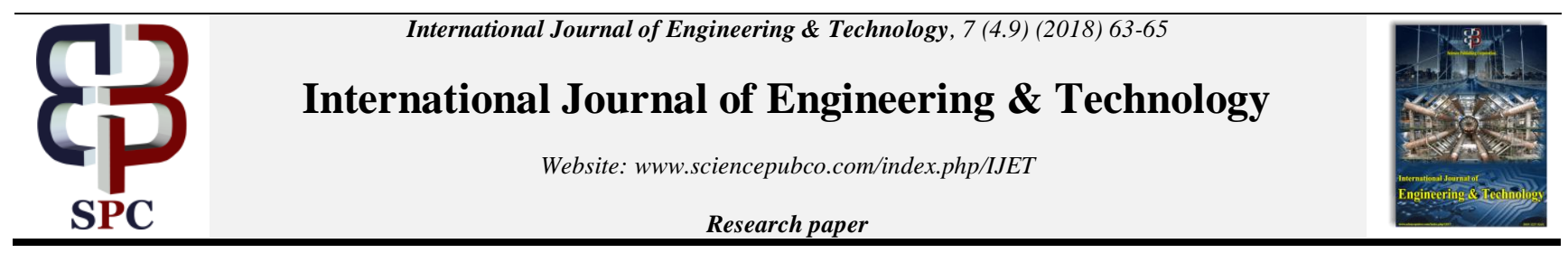

\title{
Psychological capital, work well-being, and job performance
}

\author{
Rizal Nangov ${ }^{*}$, Sasmoko ${ }^{2}$, Yasinta Indrianti ${ }^{3}$ \\ ${ }^{I}$ Management Department, BINUS Business School, Doctor of Research in Management, Bina Nusantara University \\ ${ }^{2}$ Primary Teacher Education Department Faculty of Humanities and Research Interest Group in Educational Technology \\ Bina Nusantara University \\ ${ }^{3}$ Research Interest Group in Educational Technology Bina Nusantara University and Faculty of Social Podomoro University \\ *Corresponding author E-mail: rizalmmgd@gmail.com
}

\begin{abstract}
Performance as a multidimensional concept has become a very interesting variable to be studied especially in the viewpoint of positive psychology. This study aims to see the influence of Psychological Capital and Work Well Being as an element in the positive psychology of Job Performance. The research method used is a quantitative method with survey technique. The results showed that Psychological Capital had a positive and significant impact on Job Performance as well as Worl Well Being. These results are expected to contribute positively to human resource managers so that the measurement of performance can be done by considering the various multidimensional components that influence it.
\end{abstract}

Keywords: Job Performance, Psychological Capital, Work Well Being

\section{Introduction}

Performance is a very interesting term and continues to serve as a research topic in various fields. Performance has a broad spectrum and is a continuum of human action [1]. Many studies have tried to see the performance from various angles both theoretically and practically so as to produce some interaction models that show factors that can influence job performance. This is important because performance is a factor that determines the sustainability of the company [2].

Performance is basically related to the actions performed by employees and is influenced by the personality it possesses [3]. The performance also refers to the overall behavior and activities that support the achievement of corporate goals [4]. So employees who have high performance is the employees who are able to provide the best work and quality results so as to have an impact on the operational effectiveness of the company [5].

As a multidimensional concept, performance is often not easy to explain in more detail when applied in work [6]. Performance is not only related to the work but also depends on the performance work process which is also a complex factor because it has various components that influence it [7]. One of them is psychological capital where psychological capital is closely related to job performance.

Psychological capital is considered as a latent factor that describes the hope, resilience, optimism, and efficacy. Some experts include psychological capital in the concept of positive psychology because psychological capital focuses on capacity building efforts of a person $[8,9]$. Psychological capital is considered as a core factor in a person's performance because of the complexity of the aspects present in it capable of providing both cognitive and motivational effects that support each process to produce optimal performance [9]. In America, psychological capital is the most powerful factor and provides proven recommendations in performance programs.
Psychological capital significantly affects the positive work attitude of employees to perform the actions expected by the company through their performance [10].

Success in the workplace and the performance of a person in a behavioristic concept depends not only on a person's psychological capital. Behavioral studies find other equally important factors related to psychological health commonly known as well-being. Well-being also includes a concept in positive psychology that can describe the happiness and satisfaction of a person for his life [11, 12]. For the company, this concept is very important. Well-being can assist employees in optimizing the function in itself so that it will positively impact on the resulting performance [13]. By looking at the multidimensional concepts that exist in these three variables, the study attempts to examine the relationship between psychological capital, work well-being to job performance.

\section{Literature review}

\subsection{Job performance}

Job performance is a dynamic concept because it involves a variety of understanding of one's behavior. Job performance is formed by three main dimensions, namely task performance, contextual performance and adaptive performance [14]. Task performance is often referred to as core technical terminology which refers to the specific behaviors employed by employees in relation to the main tasks and responsibilities of the work they possess $[614,15]$.

Contextual performance is more related to other behaviors that support activities and maintain core tasks so they can be more efficient and effective at work [14]. In other words, task performance is more determined by role behavior while contextual performance is more determined by extra-role behavior [16].

While adaptive performance relates to the ability of employees to adapt to each change either individually, team or organization. 
Adaptive performance is important because employees are still able to perform best in a variety of conditions that are not always favorable [17].

\subsection{Psychological capital}

The concept of psychological capital was developed by Fred Luthans. Psychological capital is a positive psychological condition that is owned by a person. Psychological capital has four basic dimensions, namely 1) confidence to make the necessary efforts to accomplish a challenging task called self-efficacy; 2) create a positive attribute to present and future success called optimism; 3) persevering toward goals so that they know when they are needed and when to direct oneself to keep the goals cited as hopes and capabilities of self-defense and resurrection for greater success $[18,19,20]$ when faced with problems and difficulties called resilience [18].

\subsection{Work wellbeing}

The concept of wellbeing focuses on how a person evaluates himself/herself to various life experiences held in a positive perspective, both cognitively and affectively, to include various terms in which happiness, morality and positive affect [11]. Longitudinal studies have found that well-being has a positive impact on health and age thereby increasing one's productivity [21].

The concept of well-being in work has a broader meaning. Work well-being is the psychological condition of the individual who is satisfied and comfortable with his life, more often having positive affection, autonomy, being able to accept himself and the environment as he is, feeling a clear life goal, feeling selfdeveloping, and able to cope with stress at work.

Work well-being is supported by several dimensions that shape it. 1) Self-acceptance is the first dimension that shows a positive attitude so as to accept yourself as it is; 2) Autonomy, namely the ability to self-directed and self-regulating behavior; 3) environmental mastery, namely the ability of individuals to manipulate and control the environment both physically and mentally; 4) personal growth, namely the ability of a person in developing the potential possessed in a sustainable manner; 5) purpose in life, namely the ability to understand the purpose and direction of life and belief in the purpose; 6) good personal relationship with others who demonstrate the individual's ability to nurture warmth and relationship with others and general work-life satisfaction, that is, employees' satisfaction over their whole life $[22,23,24]$

\section{Research method}

This study uses quantitative methods with survey techniques using three research instruments, namely instruments Job Performance, Psychological Capital and Work Well Being. The Job Performance instrument consists of three dimensions: Task Performance, Contextual Performance, and Adaptive Performance. Instrument Psychological Capital consists of four dimensions of Self Efficacy, Hope, Optimism, and Resilience. While Work WellBeing instruments consist of Self-acceptance, Autonomy, Environmental Mastery, Personal Growth, Purpose in Life, and Good Personal Relationship. The instrument has been tested to see its validity and reliability. Table 1 shows the results of model testing with Confirmatory Factor Analysis. While Table 2 shows the result of instrument reliability test.
Table 1. Measurement model with CFA results

\begin{tabular}{|c|c|c|c|}
\hline Construct & Dimension & $\begin{array}{l}\text { Standardized } \\
\text { factor loadings }\end{array}$ & Conclusion \\
\hline Psycap & $\begin{array}{l}\text { SE } \\
\text { HO } \\
\text { OP } \\
\text { RE }\end{array}$ & $\begin{array}{l}0.95>0.50 \\
0.90>0.50 \\
0.95>0.50 \\
0.89>0.50\end{array}$ & $\begin{array}{l}\text { Valid } \\
\text { Valid } \\
\text { Valid } \\
\text { Valid }\end{array}$ \\
\hline $\begin{array}{l}\text { Work well- } \\
\text { being }\end{array}$ & $\begin{array}{l}\text { SA } \\
\text { OT } \\
\text { EM } \\
\text { PG } \\
\text { PL } \\
\text { PR } \\
\text { LS }\end{array}$ & $\begin{array}{l}0.68>0.50 \\
0.93>0.50 \\
0.82>0.50 \\
0.80>0.50 \\
0.62>0.50 \\
0.67>0.50 \\
0.92>0.50\end{array}$ & $\begin{array}{l}\text { Valid } \\
\text { Valid } \\
\text { Valid } \\
\text { Valid } \\
\text { Valid } \\
\text { Valid } \\
\text { Valid }\end{array}$ \\
\hline $\begin{array}{l}\text { Job Perfor- } \\
\text { mance }\end{array}$ & $\begin{array}{l}\text { TaskPer } \\
\text { ContextPer } \\
\text { AdaptPer }\end{array}$ & $\begin{array}{l}0.91>0.50 \\
0.97>0.50 \\
0.67>0.50\end{array}$ & $\begin{array}{l}\text { Valid } \\
\text { Valid } \\
\text { Valid }\end{array}$ \\
\hline
\end{tabular}

Table 2. Reliability testing

\begin{tabular}{|l|c|c|c|}
\hline Construct & $\begin{array}{c}\text { Construct } \\
\text { reliability }\end{array}$ & $\begin{array}{c}\text { Variance } \\
\text { extracted }\end{array}$ & Conclusion \\
\hline Psycap & $0.96>0.70$ & $0.85>0.50$ & Reliable \\
Work well-being & $0.92>0.70$ & $0.62>0.50$ & Reliable \\
Job Performance & $0.89>0.70$ & $0.74>0.50$ & Reliable \\
\hline
\end{tabular}

\section{Results}

The results showed that both variables, namely Psychological Capital and Work Well Being positively and significantly influence Job Performance. In the first hypothesis test, Psychological Capital was positively associated with Work Well Being with a t-value of 5.49. While in the second hypothesis test shows that Work Well Being positively related to Job Performance with t-value of 2.01. And in the third hypothesis test, Psychological Capital positively affects Job Performance with the $t$ value of 4.71 . Hypothesis test results can be seen in table 3

Table 3. Hypothesis testing

\begin{tabular}{|c|c|c|}
\hline Hypothesis & t-value & Conclusion \\
\hline $\begin{array}{l}\text { H1: Employee psycho- } \\
\text { logical capital is posi- } \\
\text { tively correlated with } \\
\text { work well-being }\end{array}$ & $5.49>1.96$ & $\begin{array}{l}\text { H1 accepted, supported } \\
\text { by empirical data }\end{array}$ \\
\hline $\begin{array}{l}\mathrm{H} 2 \text { : Employee work } \\
\text { well-being is positively } \\
\text { correlated with job per- } \\
\text { formance }\end{array}$ & $2.01>1.96$ & $\begin{array}{l}\mathrm{H} 2 \text { accepted, supported } \\
\text { by empirical data }\end{array}$ \\
\hline $\begin{array}{l}\text { H3: Employee psycho- } \\
\text { logical capital is posi- } \\
\text { tively correlated with } \\
\text { job performance }\end{array}$ & $4.71<1.96$ & $\begin{array}{l}\mathrm{H} 3 \text { accepted, supported } \\
\text { by empirical data }\end{array}$ \\
\hline
\end{tabular}

The description of the research model with reference to the research results can be seen in Figure 1 below.

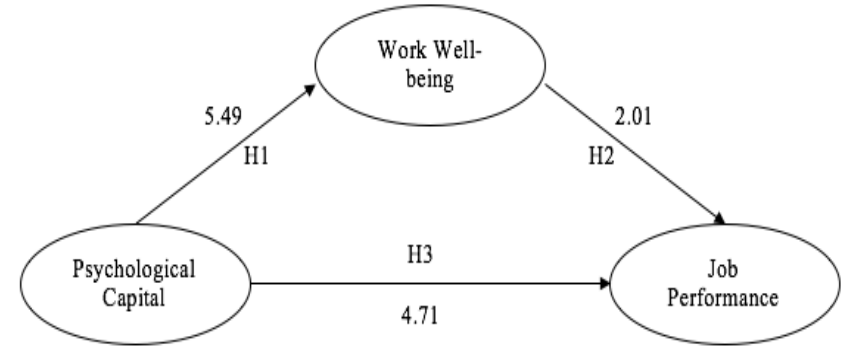

Fig. 1. Research model with $t$-values $(\mathrm{p}<0.05)$ 


\section{Discussion and conclusion}

The results have shown that Psychological Capital and Work Well Being positively have a significant impact on Job Performance. This is important because performance is the result of an action. So the job performance needs to be studied further both theoretically and practically so as to capture the various components that influence it [1]. This research finds the role of multidimensional between psychological capital variable and works well being toward performance so that it strengthens that job performance is a multidimensional concept which has many influential factors. But the most important job performance is determined by various positive conditions that have a person so that the concept of positive psychology into an indicator that needs to be considered in the management of human resources.

\section{Limitation and future research}

Some limitations in this study provide the basis for researchers to provide suggestions and improvements to similar research that will be done in the future. The limitation in this research is that the researcher does not conduct an objective measurement of performance where the questionnaire is only given to be filled directly by the employee. In the next research, it is better if the performance appraisal also involves superiors, colleagues, and users to be able to get a more objective picture of employee performances

\section{Biographies}

Rizal Nangoy is a student in Doctor of Research in Management, Binus University, Jakarta. He earned Bachelor of Engineering from Metallurgical Department, Faculty of Engineering, University of Indonesia, Master of Management from PPM School of Management, Master of Science in Psychology from Tarumanagara University. Mr. Rizal has more than 18 years working experience and currently as CEO of a national leading company in Jakarta. He also acts as a part-time lecturer at PPM School of Management taught course strategic management, ethical leadership, and system dynamics. He has a strong interest in strategic management, supply chain management, organizational behavior, as well as industrial and organizational psychology.

\section{References}

[1] Schechner R (2013), What is Performance Studies? Rupkatha Journal on Interdisciplinary Studies in Humanities on Interdisciplinary Studies in Humanities (2), 11.

[2] Almutairi DO (2016), The Mediating Effects of Organizational Commitment on the Relationship between Transformational Leadership Style and Job Performance. International Journal of Business and Management, 11(1), 231-241. https://doi.org/10.5539/ibr.v7n11p126

[3] Judge TA \& Zapata CP (2015), The person-situation debate revisited: Effect of situation strenght and trait activation on the validity of the Big Five Personality Traits in predicting job performance. Academy of Management Journal 58(4), 1149-1179.

[4] Campbell CH, Ford P, Rumsey MG \& Pulakos ED (1990), Development of Multiple Job Perfromance Measures in a Representative Sample of Jobs. Personnel Psychology 43, 200-277.

[5] Muindi F \& Obonyo PK (2015), Quality of Work Life, Personality, Job Satisfaction, Competence, and Job Performance: A Critical Review of Literature 11(26), 223-240.

[6] Koopmans L, Bernaards CM, Hildebrandt VH, Schaufeli WB, de Vet Henrica CW \& van der Beek AJ (2011), Conceptual Frameworks of Individual Work Performance. Journal of Occupational and Environmental Medicine 53(8), 856-866. https://doi.org/10.1097/JOM.0b013e318226a763

[7] Bakker AB \& Leiter MP (2010), Work Engagement - A Handbook of Essential Theory and Research. East Sussex: Psychology Press.
[8] Luthans F, Norman SM, Avolio BJ \& Avey JB (2008), The mediating role of psychological capital in the supportive organizational climate - Employee performance relationship. Journal of Organizational Behavior 29(2), 219-238. https://doi.org/10.1002/job.507

[9] Youssef CM \& Luthans F (2007), Positive Organizational Behavior in the Workplace: The Impact of Hope, Optimism, and Resilience. Journal of Management 33(5), 774-800. https://doi.org/10.1177/0149206307305562

[10] Avey JB, Reichard RJ, Luthans F \& Mhatre KH (2011), Metaanalysis of the impact of positive psychological capital on employee attitudes, behaviors, and performance. Human Resource Development Quarterly, 22(2), 127-152. https://doi.org/10.1002/hrdq.20070

[11] Diener E (1984), Subjective Well Being. Psychological Bulletin 95, $542-575$.

[12] Diener E, Oishi S \& Lucas RE (2003), Personality, Culture, and Subjective Well-Being: Emotional and Cognitive Evaluations of Life. Annual Review of Psychology 54(1), 403-425. article. https://doi.org/10.1146/annurev.psych.54.101601.145056

[13] Kooij DTAM, Guest DE, Clinton M, Knight T, Jansen PGW \& Dikkers JSE (2013), How the impact of HR practices on employee well-being and performance changes with age. Human Resource Management Journal 23(1), 18-35. https://doi.org/10.1111/17488583.12000

[14] Rotundo M \& Sackett PR (2002), The Relative Importance of Task, Citizenship and Counterproductive Performance to Global Ratings of Job Performance: A Policy-Capturing Approach. Journal of Applied Psychology 87(1), 66-80.

[15] Koopmans L, Bernaards CM, Hildebrandt VH, Van Buuren S, Van der Beek AJ \& De Vet HCW (2013), Development of an individual work performance questionnaire. International Journal of Productivity and Performance Management 62(1), 6-28. https://doi.org/10.1108/17410401311285273

[16] Motowidlo SJ \& Van Scotter JR (1994), Evidence That Task Performance Should Be Distinguished From Contextual Performance. Journal of Applied Psychology 79(4), 475-480. https://doi.org/10.1037/0021-9010.79.4.475

[17] Griffin MA, Neal A, Parker SK, Griffin MA \& Parker SK (2007), Interdependent Contexts Linked references are available on JSTOR for this article: A NEW MODEL OF WORK ROLE PERFORMANCE: POSITIVE BEHAVIOR IN UNCERTAIN AND INTERDEPENDENT CONTEXTS The University of Queensland 50(2), 327-347.

[18] Luthans F (2002), The need for and meaning of positive organizational behavior. Journal of Organizational Behavior 23(6), 695-706. https://doi.org/10.1002/job.165

[19] Luthans F, Avey JB, Avolio BJ, Norman SM \& Combs GM (2006), Psychological capital development: Toward a micro-intervention. Journal of Organizational Behavior 27(3), 387-393. https://doi.org/10.1002/job.373

[20] Luthans F, Luthans KW \& Luthans BC (2004), Positive psychological capital: Beyond human and social capital. Business Horizons 47(1), https://doi.org/10.1016/j.bushor.2003.11.007

[21] Tov W \& Diener E (2013), Subjective Wellbeing. The Encyclopedia of Cross-Cultural Psychology 1239-1245. https://doi.org/10.1002/9781118339893.wbeccp518

[22] Diener E, Wirtz D, Biswas-diener R, Tov W, Kim-prieto C, Choi D \& Oishi S (2009), Assessing Well-Being. Assessing Well-Being39. https://doi.org/10.1007/978-90-481-2354-4

[23] Ryff CD (1989), Happiness is everything, or is it? explorations on the meaning of psychological well-being. Journal of Personality \& Social Psychology 57(6), 1069-1081. https://doi.org/10.1037//0022-3514.57.6.1069

[24] Ryff CD (1995), Psychological Weil-Being. Current Directions in Psychological Science 4(4), 99-104. 